\title{
First record of Synidotea laticauda Benedict, 1897 (Crustacea: Isopoda) in the Guadiana Estuary (SW Iberian Peninsula)
}

\author{
Carlos Nuño,,*, María Peg1, Andrés Mellado-Díaz ${ }^{1,2}$, Jorge Rubén Sánchez-González ${ }^{1,3}$ and \\ Manuel Toro ${ }^{1}$
}

1 Área de Medio Ambiente Hídrico. Centro de Estudios Hidrográficos (CEDEX). Paseo Bajo de la Virgen del Puerto, 3. 28005, Madrid. Spain.

2 DBO5 S.L. C/ Artesanía 23, Mairena del Aljarafe, 41927 Sevilla. Spain.

3 TRAGSATEC. Calidad, Evaluación Ambiental y Medio Natural. C/ Julián Camarillo, 6 B, 28037, Madrid. Spain.

* Corresponding author: carlos.nuno@cedex.es

Received: $11 / 08 / 17 \quad$ Accepted: 04/01/18

\begin{abstract}
First record of Synidotea laticauda Benedict, 1897 (Crustacea: Isopoda) in the Guadiana Estuary (SW Iberian peninsula)

The exotic isopod species Synidotea laticauda B. 1897 is first reported in the Guadiana Estuary, where it was detected, during 2009 and 2010, in the middle section (12-20 km from the mouth) and in the lower part of the upper sections (20-70 km from the mouth), where the species presented its optimal temperature and conductivity ranges between $11^{\circ} \mathrm{C}$ and $21{ }^{\circ} \mathrm{C}$ and between 20000 and $25000 \mu \mathrm{S} / \mathrm{cm}$. The absence of freshwater flood events due to the construction of the Alqueva Reservoir, and the intense ship traffic along the estuary may have been decisive for the introduction and establishment of this alien species.
\end{abstract}

Key words: Synidotea laticauda, Isopoda, Guadiana Estuary, exotic species

\section{RESUMEN}

Primer registro de Synidotea laticauda Benedict, 1897 (Crustacea: Isopoda) en el estuario del Guadiana (SO de la península ibérica)

El isópodo exótico Synidotea laticauda B. 1987, ha sido localizado por primera vez en el estuario del río Guadiana. En un estudio realizado entre el año 2009 y 2010 fue encontrado en el tramo medio (12-20 km desde la desembocadura) y zona baja del alto estuario (20-70 km desde la desembocadura), presentando unos rangos óptimos de temperatura y conductividad entre $11^{\circ} \mathrm{C}$ y $21{ }^{\circ} \mathrm{C}$ y entre 20000 y $25000 \mu \mathrm{S} / \mathrm{cm}$. La modificación del régimen de caudales, debido a la construcción del embalse de Alqueva y el intenso tráfico de embarcaciones a lo largo del estuario, pueden haber contribuido a la introducción y establecimiento de esta especie.

Palabras clave: Synidotea laticauda, Isopoda, río Guadiana, estuario, especies exóticas 


\section{INTRODUCTION}

Synidotea laticauda Benedict, 1897 is native to the north-eastern Pacific region, where it was first described in San Francisco Bay, California (Benedict, 1897; Menzies \& Miller, 1972), mainly developing in warm, oligo- or mesohaline shallow intertidal waters of estuarine systems (Boyd, 2008). It is commonly found in habitats with great bio-fouling development, like berths, buoys, bumpers and other submerged structures of port facilities. It is intolerant to drastic environmental fluctuations such as strong freshwater inputs as heavy rain events, which can drastically reduce salinity or rise temperature values above $25^{\circ} \mathrm{C}$, increasing its mortality rate (Boyd, 2008). However, the species has been reported to have survived salinity increments of up to $30-35 \mathrm{~g} / \mathrm{l}$ by the same author.

Outside its native range, Synidotea laticauda has been previously cited in the Atlantic coast of USA, in Delaware Bay (Bushek \& Boyd, 2006), in the Yangtze Estuary, China (Liu et al., 2017) and in Europe, in the estuary of the Gironde

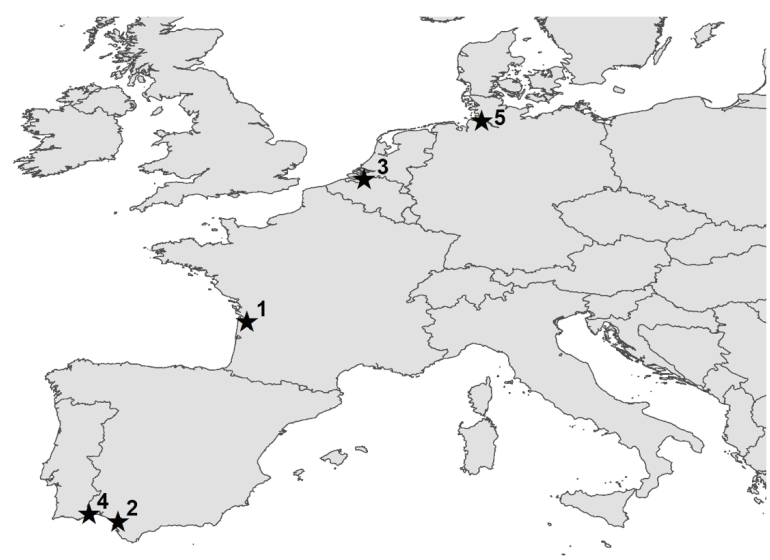

Figure 1. Current known distribution of Synidotea laticauda in Europe: in order of date of first detection, 1. Gironde Estuary, (France, 1975); 2. Guadalquivir Estuary (Spain, 1991); 3. Schelde Estuary (Belgium-Netherland, 2003); 4. Guadiana Estuary (Spain-Portugal, 2009); 5. Elbe Estuary (Germany, 2014). Distribución actual conocida de Synidotea laticauda en Europa: en orden de fecha de la primera detección, 1. Estuario de la Gironda (Francia, 1975); 2. Estuario del Guadalquivir (España, 1991); 3. Estuario de Schelde (Bélgica-Holanda, 2003); 4. Estuario del Guadiana (España-Portugal, 2009) y 5. Estuario del Elba (Alemania, 2014).
River, France (Mees \& Fockedey, 1993), the estuary of the river Guadalquivir in the Iberian Peninsula (Cuesta et al., 1996, Baldó et al., 2001), the estuary of the Schelde River, Belgium (Soors et al., 2010) and Netherlands (Faasse, 2011; Noël, 2011), and the port of Brunsbüttel, in the Elbe Estuary, Germany (ICES, 2016) (Fig.1). This note registers the first record of the exotic species Synidotea laticauda in the Guadiana Estuary, a meso-tidal $70 \mathrm{~km}$ long water body located in the southwest of the Iberian Peninsula.

\section{MATERIAL AND METHODS}

Ten sampling sites along the longitudinal axis of the Guadiana Estuary were selected, following a salinity gradient: 3 (S01, S02 y S03) in the middle estuary (mixing of fresh and sea water, $12-20 \mathrm{~km}$ from the mouth), and 7 (S04-S10) in the upper estuary (mainly freshwater, $20-70 \mathrm{~km}$ from the mouth). Benthic macroinvertebrates were sampled using artificial substrates (Table 1). Two samples per site were taken seasonally from January 2009 to February 2010. Not all sites could be analysed in all the dates (Table 1) due to the theft or loss of some of the substrates.

Each artificial substrate consisted of a $25 \mathrm{~cm}$ sided stainless steel cube covered by a plastic netting with $1 \mathrm{~cm}$ mesh size in the upper $2 / 3$, and $1 \mathrm{~mm}$ in the lower $1 / 3$, to avoid specimen loss when removing the trap from the bed. It was stuffed with organic and mineral materials, collected in the immediate surroundings (stones, reeds, etc.), and tied to the shore with a nylon line to pass unnoticed.

The retrieved substrates were cleaned by shaking them under a strong stream of water, then, using sieves, the coarser organic and inorganic matter was removed (stones, branches, twigs, etc.) after being properly cleaned. The remaining sample was fixated using ethanol $(95 \%)$ for later identification and estimation of the relative abundances in the laboratory.

At each substrate location a temperature-conductivity vertical profile from the maximum depth to the surface was performed, both in high and low tide regimes, with a multiparameter probe YSI 6600 V2. Mean values within the uppermost 4 metres (the depth range at which 
Table 1. Location of artificial substrates and sampling dates. Localización de los sustratos artificiales y fecha de muestreo.

\begin{tabular}{|c|c|c|c|c|c|c|c|}
\hline $\begin{array}{l}\text { Artificial } \\
\text { Substrates }\end{array}$ & $\begin{array}{l}\text { Coordenates } \\
\text { (UTM) }\end{array}$ & Estuary zones & $\begin{array}{c}\text { January } \\
2009\end{array}$ & $\begin{array}{l}\text { May } \\
2009\end{array}$ & $\begin{array}{c}\text { August } \\
2009\end{array}$ & $\begin{array}{l}\text { October } \\
2009\end{array}$ & $\begin{array}{c}\text { February } \\
2010\end{array}$ \\
\hline S01 & 29 S 6396824125585 & MIDDLE ESTUARY & $x$ & $x$ & $x$ & $x$ & $x$ \\
\hline S02 & 29 S 6383104131581 & MIDDLE ESTUARY & $x$ & $x$ & & & $\mathrm{x}$ \\
\hline S03 & 29 S 6385764136579 & MIDDLE ESTUARY & $x$ & $x$ & $\mathrm{x}$ & $x$ & $\mathrm{x}$ \\
\hline S04 & $29 \mathrm{~S} 6372334140675$ & UPPER ESTUARY & $\mathrm{x}$ & $x$ & $\mathrm{x}$ & $x$ & $x$ \\
\hline S05 & $29 \mathrm{~S} 6367594143057$ & UPPER ESTUARY & $\mathrm{x}$ & & $\mathrm{x}$ & $x$ & $x$ \\
\hline s06 & $29 \mathrm{~S} 6355604147155$ & UPPER ESTUARY & $\mathrm{x}$ & & $\mathrm{x}$ & $\mathrm{x}$ & \\
\hline S07 & 29 S 6353774150654 & UPPER ESTUARY & & $\mathrm{x}$ & $\mathrm{x}$ & & $\mathrm{x}$ \\
\hline S08 & $29 \mathrm{~S} 6333164152308$ & UPPER ESTUARY & $\mathrm{x}$ & $\mathrm{x}$ & & & $\mathrm{x}$ \\
\hline S09 & $29 S 6315534153972$ & UPPER ESTUARY & $\mathrm{x}$ & $\mathrm{x}$ & $\mathrm{x}$ & $\mathrm{x}$ & $\mathrm{x}$ \\
\hline $\mathrm{S} 10$ & 29 S 6307014156927 & UPPER ESTUARY & $\mathrm{x}$ & $\mathrm{x}$ & $\mathrm{x}$ & $\mathrm{x}$ & $\mathrm{x}$ \\
\hline
\end{tabular}

substrates were submerged) were selected to characterize each sample.

The estimation of the optimal range of temperature and conductivity of S. laticauda in the estuary was determined according to the robust optima method (Cristobal et al., 2014). This method is based on the median and the interquartile range. The calculation is made assuming that each value of the observed environmental variable is given with a probability proportional to the number of individuals found;

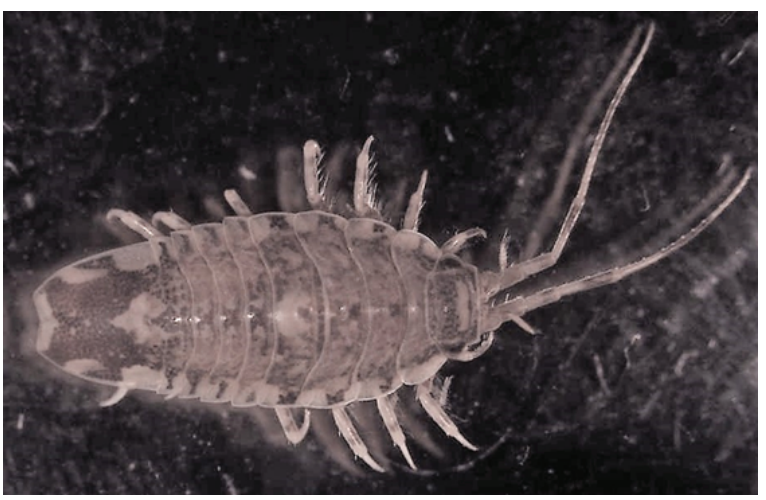

Figure 2. Picture of Synidotea laticauda collected from the Guadiana Estuary. Fotografia de Synidotea laticauda capturada en el estuario del Guadiana. the median and interquartile range of this discrete distribution is calculated. This is equivalent to defining the optimal as the median, and the tolerance as the interquartile range for the sample formed by each of the found individuals (Cristobal et al., 2014).

\section{RESULTS AND DISCUSSION}

Over 300 individuals of Synidotea laticauda (Fig.2) were collected in 4 of the 10 sampled sites: three in the middle estuary (substrates S1 to S3) and one in the lower part of the upper estuary (S4 substrate) (Table 2).

The species presented its highest abundance in a temperature range from 10 to $25{ }^{\circ} \mathrm{C}$ (Fig.3) and conductivities ranking from 500 to $33800 \mu \mathrm{S} / \mathrm{cm}$ (Fig. 4), being its optimal ranges from $11{ }^{\circ} \mathrm{C}$ to $21^{\circ} \mathrm{C}$ and from 20000 to $25000 \mu \mathrm{S} / \mathrm{cm}$ (Fig. 5). These data resemble those observed for the native distribution of the species (Boyd, 2008).

The most common species found to co-occur with Synidotea laticauda were the following: Cyathura carinata, Leptocheirus pilosus, Balanus sp., Corophium sp., Gammarus sp., Palaemon longirostris, Carcinus maenas, Sphaeroma serratum, Ostrea sp., Oligochaeta, Hediste diversicolor and Nereis sp. 
Table 2. Artificial substrates where Synidotea laticauda has been found. Sustratos artificiales donde se ha localizado Synidotea laticauda.

\begin{tabular}{ccccc}
\hline Date & Substrate & $\begin{array}{c}\text { Num. } \\
\text { individuals }\end{array}$ & $\begin{array}{c}\text { Conductivity } \\
(\boldsymbol{\mu S} / \mathbf{c m})\end{array}$ & Temp $\left({ }^{\circ} \mathrm{C}\right)$ \\
\hline January 2009 & $\mathrm{S} 01$ & 41 & $25916-25674$ & $11.42-11.38$ \\
& $\mathrm{~S} 04$ & 20 & $504-528$ & $10.34-10.26$ \\
\hline May 2009 & $\mathrm{S} 02$ & 24 & $2550-6108$ & $19.74-19.58$ \\
\hline August 2009 & $\mathrm{S} 03$ & 1 & 33810 & 24.95 \\
\hline & $\mathrm{S} 03$ & 8 & 30910 & 21.13 \\
October 2009 & $\mathrm{S} 04$ & 227 & 19540 & 21.22 \\
\hline
\end{tabular}

High Tide

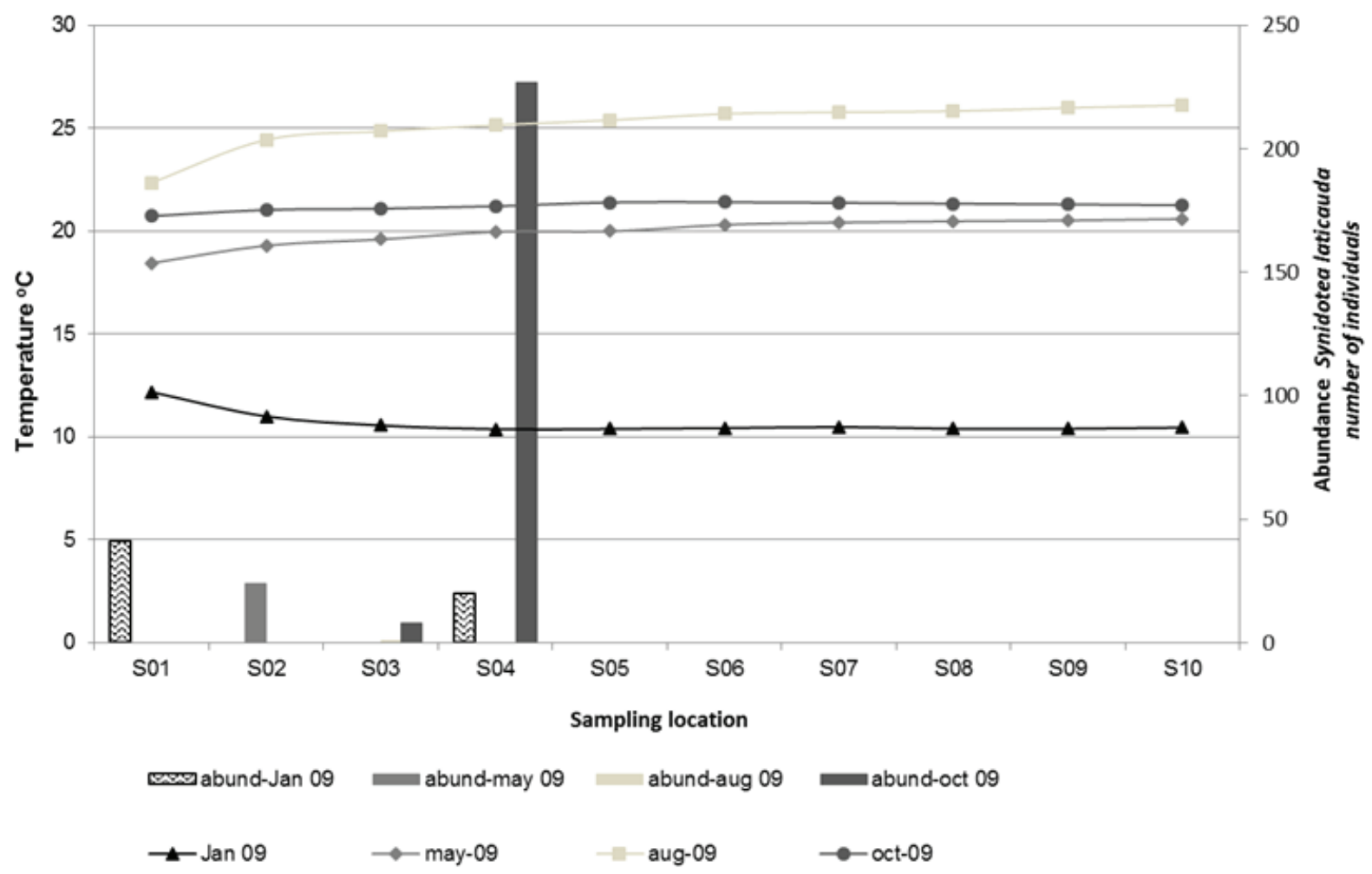

Figure 3. Abundance distribution of Synidotea laticauda in relation to the temperature gradient. Distribución de la abundancia de Synidotea laticauda en relación al gradiente de temperatura. 


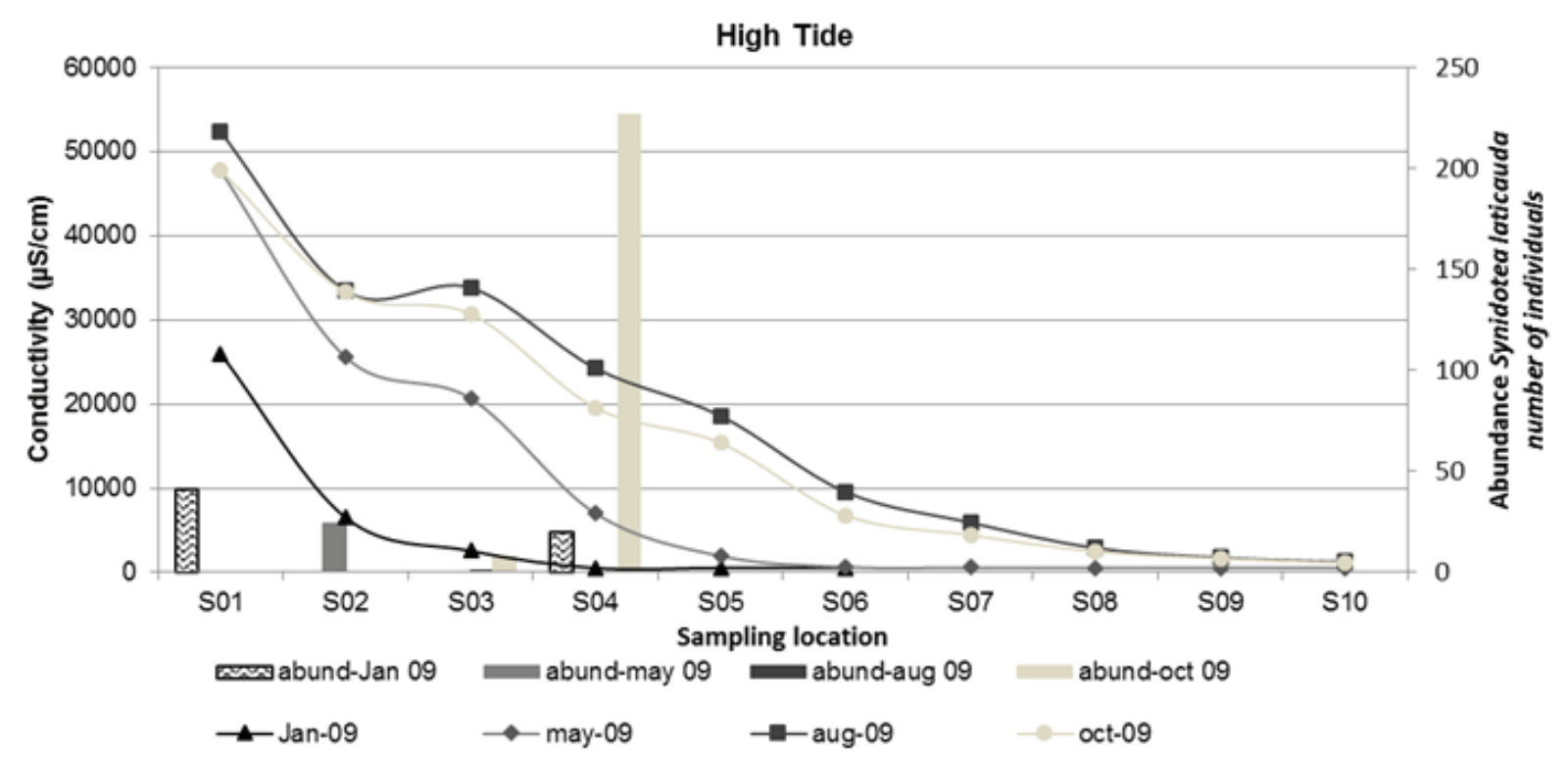

Figure 4. Abundance distribution of Synidotea laticauda in relation to the conductivity gradient. Distribución de la abundancia de Synidotea laticauda en relación al gradiente de conductividad.

Regarding the current presence of Synidotea laticauda in the studied area since 2010, only a local research group (University of Sevilla) has conducted a survey in 2016-2017 without finding the species (Sánchez-Moyano pers. com.). This fact indicates a less successful colonization in the Guadiana Estuary in comparison with the Guadalquivir Estuary, where the species can show very high densities (Ruiz-Delgado et al., 2016).

In 2002 the Alqueva Reservoir was finished, located approximately $150 \mathrm{~km}$ upstream from the Guadiana River mouth, covering an area of 250 $\mathrm{km}^{2}$ and holding up to $4150 \mathrm{hm}^{3}$ of freshwater. After its construction, a more homogeneous flow regime and a diminution of the magnitude and frequency of freshwater flood events has been reported (Morais et al., 2009; Garel \& Ferreira, 2015; Garel, 2017) as the cause of changes in macrobenthic crustaceans in the estuary (Leitão, 2008). This new homogeneous flow regime may have favoured the colonization and establishment of Synidotea laticauda in the Guadiana Estuary, as it has been the case in other studies (Bunn \& Arthingthon, 2002; Johnson et al., 2008). Shipping traffic of medium and small vessels along the lower $50 \mathrm{~km}$ of the Guadiana Estuary, mainly for recreational use, and coming from all over the world, could have acted as vectors for the accidental introduction of this species. Some authors have also reported recent alien species invasions and establishment in this estuary and nearby salt marshes, and have pointed to shipping traffic and flow regulation as potential causes (Chícharo et al., 2009; Gonçalves et al., 2017).

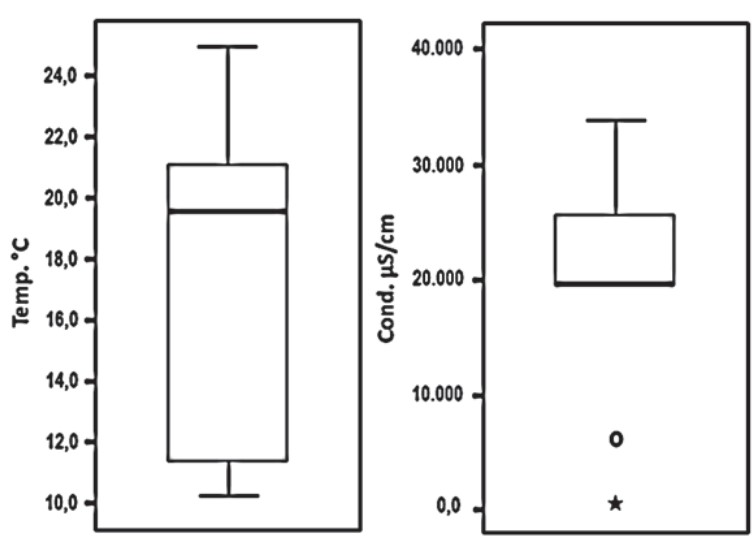

Figure 5. Optimum range of tolerance of Synidotea laticauda according to temperature and conductivity. Rango óptimo de tolerancia de Synidotea laticauda con respecto a temperatura y conductividad. 


\section{ACKNOWLEDGEMENTS}

This study has been funded by a Management Delegation Agreement of the Ministry of the Environment (General Directorate of Water) to CEDEX (2007-2013). A. Rasines helped in laboratory works and $\mathrm{F}$. Mengibar, M. Verdugo, S. Arias and J. Moreno in field works, and J. Sánchez for hand-making and repairing some of the artificial substrates. We are very grateful to Dr. J.E. Sánchez Moyano (University of Sevilla) for the confirmation of the taxonomic identification of the species.

\section{REFERENCES}

BALDÓ, F., M.A. ARIAS \& P. DRAKE. 2001. La comunidad macrobentónica del estuario del Guadalquivir. Boletín del Instituto Español de Oceanografía. 17 (1-2): 137-148.

BENEDICT, J.E. 1897. A revision of the Genus Synidotea. Proceedings of the Academy of Natural Sciences of Philadelphia, 49: 389-404.

BOYD, S.G. 2008. An ecological assessment of the non-indigenous isopod, Synidotea laticauda, in Delaware Bay. Ph.D. Thesis, Master of Science. Graduate Program in Ecology and Evolution. The State University of New Jersey. USA. 82 pp.

BUNN, S. \& A. ARTHINGTON. 2002. Basic principles and ecological consequences of altered flow regimes for aquatic biodiversity. Environmental Management, 30 (4): 492-507. DOI: $10.1007 / \mathrm{s} 00267-002-2737-0$

BUSHEK, D. \& S. BOYD. 2006. Seasonal abundance and occurrence of the Asian isopod Synidotea laevidorsalis in Delaware Bay, USA. Biological Invasions, 8: 697-702. DOI: 10.1007/s10530-005-2890-5

CHÍCHARO, M.A., T. LEITÃO, P. RANGE, C. GUTIERREZ, J. MORALES, P. MORAIS \& L. CHÍCHARO. 2009. Alien species in the Guadiana Estuary (SE-Portugal/SW-Spain): Blackfordia virginica (Cnidaria, Hydrozoa) and Palaemon macrodactylus (Crustacea, Decapoda): potential impacts and mitigation measures. Aquatic Invasions, 4 (3): 501-506. DOI: 10.3391/ai.2009.4.3.11

CRISTOBAL, E., S. VELASCO, A. JUSTEL \&
M. TORO. 2014. Robust optima and tolerance ranges of biological indicators: a new method to identify sentinels of global warming. Ecological Research, 29 (1), 55-68. DOI: 10.1007/s11284-013-1099-9

CUESTA J.A., L. SERRANO, M.R. BRAVO \& J. TOJA. 1996. Four new crustaceans in the Guadalquivir river estuary (SW Spain), including an introduced specie. Limnetica, 12 (1): 41-45.

FAASSE, M. 2011. The exotic isopod Synidotea in the Netherlands and Europe, a Japanese or American invasion (Pancrustacea: Isopoda)? Nederlandse Faunistische Mededelingen, 36: 103-106.

GAREL, E. 2017. Present dynamics of the Guadiana estuary. In: Guadiana River estuary - Investigating the past, present and future. MOURA, D., A. GOMES, I. MENDES \& J. ANÍLBAL (eds.): 15-37. 1st edition. University of Algarve. Faro, ISBN 978-989-8859-18-1.

GAREL, E. \& Ó. FERREIRA. 2015. Multi-year high-frequency physical and environmental observations at the Guadiana Estuary. Earth System Science Data, 7: 299-309. DOI: 10.5194/essd-7-299-2015

GONÇALVES, R., M.A. TEODÓSIO, J. CRUZ, R. BEN-HAMADOU, A.D. CORREIA \& L. CHÍCHARO. 2017. Preliminary insight into winter native fish assemblages in Guadiana estuary salt marshes coping with environmental variability and non-indigenous fish introduction. Fishes, 2 (19): 1-14. DOI: 10.3390/ fishes 2040019

ICES. 2016. Report of the Working Group on Introductions and Transfers of Marine Organisms (WGITMO), 16-18 March 2016, Olbia, Italy. ICES CM 2016/SSGEPI:10. 201 pp.

JOHNSON, P.T., J.D. OLDEN \& M.J. VANDER ZANDEN. 2008. Dam invaders: impoundments facilitate biological invasions into freshwaters. Frontiers in Ecology and the Environment, 6: 357-363. DOI: $10.1890 / 070156$

LEITÃO, T. 2008. Efeito do caudal na estrutura das comunidades de crustáceos macrobentónicos no estuário do Guadiana. Master thesis. Faro, University of Algarve, Portugal, 78 pp. 
LIU, W., X. LIANG \& X. ZHU. 2017. A new record and mitochondrial identification of Synidotea laticauda Benedict, 1897 (Crustacea: Isopoda: Valvifera: Idoteidae) from the Yangtze Estuary, China. Zootaxa, 4294 (3): 371-380. DOI: 10.11646/zootaxa.4294.3.7

MEES, J. \& N. FOCKEDEY. 1993. First record of Synidotea laevidorsalis (Miers, 1881) (Crustacea: Isopoda) in Europe (Gironde estuary, France). Hydrobiologia, 264: 61-63. DOI: $10.1007 /$ BF00014665

MENZIES, R.J. \& M.A. MILLER. 1972. Systematics and zoogeography of the genus Synidotea (Crustacea: Isopoda) with an account of Californian species. Smithsonian Contributions to Zoology, 102: 1-33. DOI: 10.5479/ si.00810282.102

MORAIS, P., M.A. CHÍCHARO \& L. CHÍCHARO. 2009. Changes in a temperate estuary during the filling of the biggest European dam. Science of the Total Environment, 407: 2245-2259. DOI: 10.1016/j.scitotenv.
2008.11.037

NOËL, P.Y. 2011. Checklist of Cryptogenic and Alien Crustacea of the European Atlantic Coast. In: In the Wrong Place - Alien Marine Crustaceans: Distribution, Biology and Impacts. GALIL, B., CLARK, P. \& J. CARLTON (eds.): $345-375$. Springer Series in Invasion Ecology, vol 6. Springer, Dordrecht. DOI: 10.1007/978-94-007-0591-3

RUIZ-DELGADO, M.C., E. GONZÁLEZ-ORTEGÓN, I. HERRERA, B. ALMÓN, P. DRAKE, C. VILAS \& F. BALDÓ. 2016. Distribution and salinity tolerance of the invasive isopod Synidotea laticauda in the Guadalquivir estuary (SW Spain): Field and laboratory observations. Poster P1.055.ECSA56 - Oxford Abstracts: Elsevier Conference Services.

SOORS, J., M. FAASEE, M. STEVENS, I. VERBESSEM, N. DE REGGE \& E. VAN DEN BERGH. 2010. New crustacean invaders in the Schelde estuary (Belgium). Belgian Journal of Zoology, 140 (1): 3-10. 